\title{
TV/Series
}

3 | 2013

Écho et reprise dans les séries télévisées (I) : Reprise et intermédialité

\section{Recurrence, Remediation and Metatextuality in Queer As Folk}

\section{Monica Michlin}

\section{(2) OpenEdition Journals}

Electronic version

URL: http://journals.openedition.org/tvseries/725

DOI: $10.4000 /$ tvseries.725

ISSN: 2266-0909

Publisher

GRIC - Groupe de recherche Identités et Cultures

Electronic reference

Monica Michlin, « Recurrence, Remediation and Metatextuality in Queer As Folk », TV/Series [Online]

3 | 2013, Online since 15 September 2013, connection on 20 April 2019. URL : http://

journals.openedition.org/tvseries/725; DOI : 10.4000/tvseries.725

\section{(c) (i) (9)}

TV/Series est mis à disposition selon les termes de la licence Creative Commons Attribution - Pas d'Utilisation Commerciale - Pas de Modification 4.0 International. 


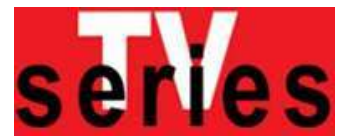

\section{Recurrence, Remediation and Metatextuality in Queer As Folk}

This article examines how recurrence functions diegetically within the series Queer As Folk (Showtime, 2000-2005), and how variations on the same event - the gay-bashing of Justin - are deliberately woven into the narrative. As a charged element within the soap opera framework of the series and within its political discourse, the bashing is reprised in a series of inset remediations (comics, theatrical show, storyboard to a Hollywood film, short sequences of animated film). This intermediality can be read as a form of hypertext and of multiplatform storytelling, as well as the series' metatextual image for itself. I will argue that remediation allows the series to articulate subversive messages, both in highlighting the queer subtext in established mainstream popular culture genres (comics, action hero films) and in highlighting the series' own singular achievement, beyond the creation of an "out" gay comics hero: the queering of soap itself.

$\mathrm{T}$

his paper shall examine how recurrence functions diegetically within the series Queer As Folk ${ }^{1}$ (Showtime, 2000-2005), and how the reprising of one major event - the gay-bashing of Justin, the cliffhanger Season 1 ends on - structures the narrative. Because this hate crime is a charged element within the soap opera framework of the series and within its political discourse, it is hardly surprising that it is taken up in a series of inset remediations²: Brian, Justin's lover and helpless witness to the attack, is remediated into the superhero Rage and the series itself into the Rage comics, floorshow, and storyboard. This intermediality, while it can be seen as a marketing strategy (the choice of multiplatform storytelling3), can also be read as a form of centrifugal hypertextuality and as the series' metatextual image for itself.

While the mise en abyme of a series, often in the form of a film within the series or a TV series within the series, is frequently a symptom of entropy (cases in point: the inset film in The L Word ${ }^{4}$

${ }^{1}$ Henceforward $Q A F$.

2 Jay David Bolter and Richard Grusin defined the concept of "remediation" in their groundbreaking study Remediation: Understanding New Media, Cambridge (MA), MIT Press, 1999. Grusin has more recently summarized the concept thus: "In Remediation we offered the following restatements of remediation: as the mediation of mediation; as the inseparability of mediation and reality; and as remedy or reform. (Bolter and Grusin, 1999, pp. 55-62)." (quoted in Richard Grusin, Premediation: Affect and Mediality After 9/11, New York, Palgrave Macmillan, 2010, p. 6). Remediation oscillates between two modes: immediacy, "a style of visual presentation whose goal is to make the viewer forget the presence of the medium" and hypermediacy, "a style of visual representation whose goal is to remind the viewer of the medium." (Bolter and Grusin, p. 272). All of these facets of remediation are mobilized within this reading of Queer As Folk: the "immediacy" of the filmic mode of the series is complicated by the hypermediacy of the other visual forms introduced in reprising the gay-bashing motif.

3 See Simone Murray, "Brand Loyalties: Rethinking Content Within Global Corporate Media," Media Culture \& Society, Vol. 27, No. 3, May 2005, p. 415-435

4 The L Word (Ilene Chaiken, Showtime, 2004-2009). 
Season 5 or the inset medical soap in Nip/Tuck 5 Season 5), $Q A F$ in this respect resembles Heroes (Tim Kring, NBC, 2006-2010), in that its reprising within remediation seems part of its core message and aesthetic originality ${ }^{6}$. Far from weakening the series, it allows it to articulate more subversive messages 7 , highlighting the queer subtext in established mainstream popular culture genres (comics, action hero films) and obviously reinforcing $Q A F_{\mathrm{S}} \mathrm{s}$ main achievement - the queering of soap itself. Bearing in mind that the reprisal of the first gay-bashing scene is central both to $Q A F$ s political discourse and to its soap storytelling, I will analyze how the floor show, comic book and storyboard function as a form of echoing of the series itself; how the multiple levels of storytelling, with their inset audiences, break down fourth walls and re-create a feeling of gay (or gay-friendly, if the viewers are not gay) community. I will finally focus on the plot around the adaptation of the Rage comics into film as an exposure of the "real" world queer masculinity of comics and action hero films, and of the homophobic context in which $Q A F$ stands out as a singular political achievement $^{8}$.

First, a word on the US version of $Q A F$, aired on Showtime from 2000 to 2005 , and which, while often called a "remake", is really a reprising, rewriting, and extended adaptation of the British series created by Russell T. Davies and first broadcast on Channel 4 in 1999, comprising ten episodes in all9. The American adaptation, located in Pittsburgh (though shot in Toronto), focuses on a group of gay men in their late twenties, and their relationships: Michael (Mikey), a boyish young man who has been best friends since junior high school with the handsome and cynical Brian, and their close friends, Ted and Emmett, who is as flamboyant as Ted is staid. In the pilot episode, all these men are single; on a night out at their favorite nightclub, they meet Justin, a seventeen-year-old whom Brian takes home that night. In the course of

5 Nip/Tuck (Ryan Murphy, FX, 2003-2010).

${ }^{6} \mathrm{QAF}$ s inset parody of itself (the soap opera Gay as Blazes, which Brian derides) is quite separate from its remediation of Brian into Rage and of the series itself into the Rage comics, floorshow, and storyboard.

7 On the essential issue of the ideological reasons for adapting and re-adapting a work which can also apply to a work's remediating itself in a series of variations, in a mise en abyme of adaptation - see Linda Hutcheon, A Theory of Adaptation, New York, Routledge,

${ }^{8}$ One can also see Queer As Folk US as a gay version of Sex \& The City (Darren Star, HBO, 1998-2004), just as The L Word is simultaneously a lesbian Sex \& The City and a female version of $Q A F$.

${ }^{9}$ For more on the British version, see Glyn Davis, Queer As Folk, Norfolk, Cromwell Press, 2007. On the evolution of queer characters in British TV mainly, see Glyn Davis and Gary Needham, Queer TV: Theories, Histories, Politics, New York, Routledge, 2009. Also see, on Channel 4's policies: Natalie Edwards, "From Minority to Mainstream: Channel 4's Queer Television", The Journal of e-media Studies, Vol. 2, No. 1, 2009, Dartmouth U.: http://journals.dartmouth.edu/cgi-bin/WebObjects/Journals.woa/1/xmlpage/4/article/325 All URLs in this article last consulted on August 12, 2013. 
Season 1, Brian takes in Justin whom his father has kicked out of the house, but insists, despite his obvious feelings for Justin, that they both remain free sexually. Other characters in the cast include Mikey's loving mother Debbie, who is a waitress in a diner, a lesbian couple, and of course the various men whom Mikey, Emmett or Ted fall in (and out of) love with during the course of five seasons.

While some fans prefer the original work (set in Manchester, and in which Michael was Vince, Brian was Stuart, and Justin, a fifteen-year-old called Nathan) for its more provocative and queerer rejection of "positive" images of gays, and its refusal of soap codes, the American remake's strengths are that it is infinitely better scripted, has time to develop a larger cast and more complex plot and characters, and that it successfully merges melodrama, witty dialogue, eroticism, and political activism. Doing away with the British version's lowbudget, reality TV-like approach to narrative - in its pilot episode, Vince speaks directly to the camera, in "confessional" mode, a form changed to a voice-over by Mikey in the US version - the American series evolves from a shot by shot remake of the British version's pilot episode to a truly autonomous storyline and aesthetic. The series' breaking away from its "source text" is epitomized by the finale of Season 1, when Brian, who has mocked Justin's romantic desire for an escort to his high-school prom, surprises him by showing up that night; this romantic scene is then followed by a brutal, unexpected twist, when one of the other students gay-bashes Justin, assaulting him with a baseball bat and sending him into a coma (in the last minutes of the episode). This makes for a poignant cliffhanger into Season 2 (will Justin survive?) and clearly marks the US version of $Q A F$ as soap and gay political drama simultaneously.

Let us start with the prom scene, which functions as an indirect declaration of love on Brian's part, and as a first "floor show" of sorts.

\section{The Prom as Justin's Last Dance? The Gay-Bashing}

When Brian appears at the prom in a tuxedo, as the perfect escort, the intradiegetic music changes to "Save the Last Dance For $\mathrm{Me}^{10}$ " and the lights dim. As Brian and Justin take to the dance floor, the other students, whether in shock, or awed by the beauty of the dance in its same-sex variation, cease to dance and form a circle around them ${ }^{11}$ (see Plate 1 and Plate 2). The "queering of the prom" is thus performed in front of two contrasted audiences: the (mainly) gay viewers of the series, who get their "dream prom" at last, and a mainly

${ }^{10}$ While the song is reflexive of both their "open" relationship and their commitment to each other, it will also function as a dramatic irony retrospectively (will this have been their last dance?)

${ }^{11}$ Watch the clip (start at 1'oo):

http://www.youtube.com/watch?v=Jo13iLyNRrk\&feature=related 
heterosexual inset audience, some of whom are fascinated, while some are caught in a reverse shot of shocked disbelief. The latter can (retrospectively) be read as announcing the gay-bashing. The dance is filmed from the first bars of the song to the last and turned into a magic moment by blue lighting, and fluid montage (alternating closeups of the two men's feet in perfect step, of their faces, and shots from above), to highlight the perfection of the supposedly unrehearsed twirling and dipping.

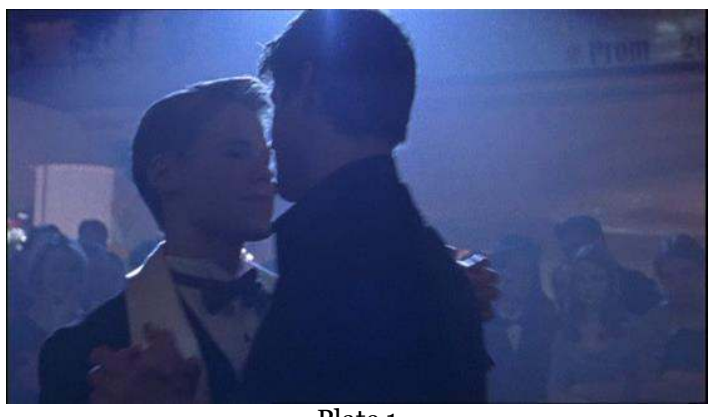

Plate 1

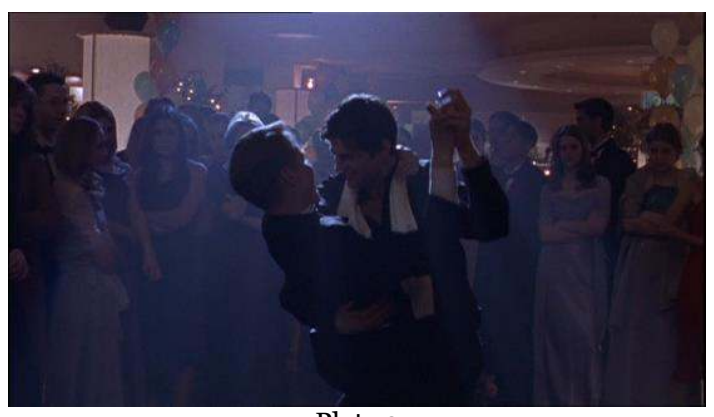

Plate 2

At the end of the song, Brian takes Justin's hand and leads him away from the prom. As we follow them into the underground parking lot, it seems clear that despite Brian's continuing verbal rejection of romantic codes ("that was ridiculously romantic"), he is enacting them: when he kisses Justin, it is precisely the prolonged romantic kiss that characterizes prom night sweethearts ${ }^{12}$ (see Plate 3). When Justin breathes that this is "the best night of [his] life", the difficulty of parting, even for a few hours - "later", says Brian, in a deferral of desire that functions as a teasing for the audience too - is emphasized through Brian's pulling him close thanks to the white satin scarf he had

${ }^{12}$ Watch the clip: http://www.youtube.com/watch?v=3xeqlimEGmE\&feature=related 
earlier draped around his neck as they whirled around the dance floor. This also functions, as Brian releases the scarf and Justin in a deliberately slow, fluid gesture, as an echo of the dance itself and of the song's lyrics ("And don't forget who's taking you home and in whose arms you're gonna be/ So darling, save the last dance for me").

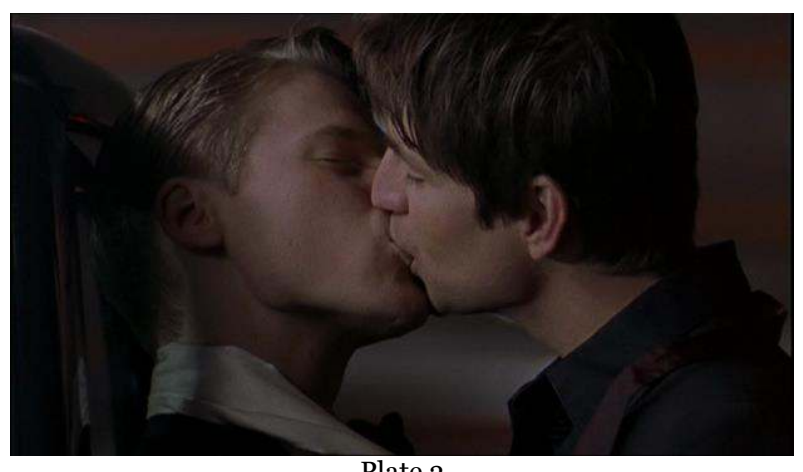

Plate 3

As Brian, now seated behind his steering wheel, fondly watches, in his rear-view mirror, Justin's back as it recedes, he suddenly sees a male figure carrying a baseball bat, sneaking up behind Justin. The cruel ironies of the expression "watching one's partner's back" (as in protecting him) and of rear-mirror views (as in hindsight) are highlighted in this shot that plays on the tragic inset frame (see Plate 4).

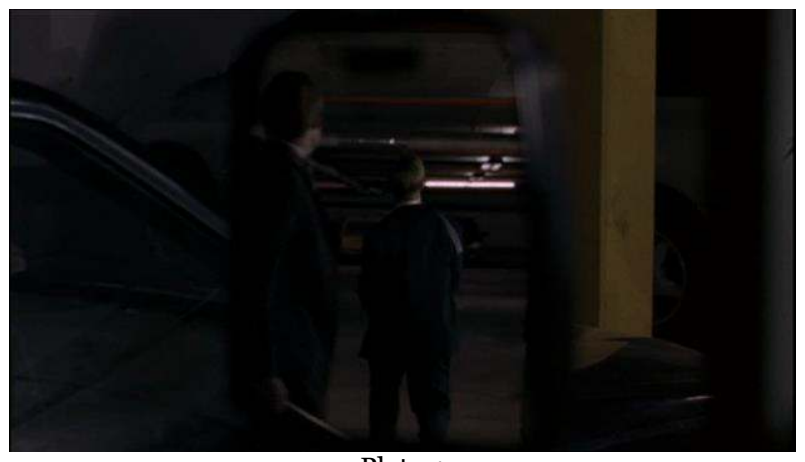

Plate 4

Brian frantically shouts out his lover's name; as Justin spins around, smiling, in a close-up of joy upon hearing Brian's voice, the bat smashes into his forehead, a tragic irony framed through Brian's gaze. 
Even as Brian spins into action, knocking down the assailant, his desperately crying out "No, no, no, no, no!" as he kneels to embrace Justin's prone body announces the tragic cliffhanger: we will see him as he sits waiting in a hospital corridor, holding his now bloodstained scarf to his face, unashamedly crying, not knowing if Justin will live. The entire sequence, from the moment Brian cries out over Justin's body to the end of the episode is wordless, to the heartbreaking soundtrack of Jan Garbarek and the Hilliard Ensemble performing "Parce Mihi Domine", creating the feeling that this is perhaps the requiem for Justin. This finale thus ends on the fear of loss, for Brian and the viewers alike, just as the relationship between Brian and Justin has visibly changed from seduction to love. The contrast between "before" and "after" is emphasized through the bloodstained scarf, perhaps already a "relic" of Justin, and through the hospital corridor as a symbolic place of "passage" between life and death: Brian, as he cries, has flashbacks, in slow motion, of the last time he was in the same hospital, running alongside both Justin and Mikey - the very same night he had met Justin and had been called to the hospital by Lindsay, his best (lesbian) friend, who was giving birth to their son. The finale thus very deliberately flashes back to the pilot episode for heightened tragic effect.

\section{Intertextual Echoing As Political Commentary}

From the point of view of its gay politics, the series may be echoing, with critical differences, the gay-bashing episode in Alan Ball's Six Feet Under (HBO, 2001-2005)13. In episode 1.12, "A Private Life", the gay victim of a hate crime whom David prepares for his funeral starts to haunt him, until in a later episode, David confronts his internalized homophobia and comes out of the closet; the ghost then is appeased. $Q A F^{\circ}$ s message is that the enemy is not within, since Justin is in no way conflicted over his identity and since he survives ${ }^{14}$. The gay-bashing, however, naturally triggers post-traumatic stress - panic attacks in crowds, fear of intimacy - depicted in the first two episodes of Season 2 to raise viewers' awareness of how survivors are haunted.

\footnotetext{
${ }_{13}$ For excellent readings of Six Feet Under, and in particular, its "queering" of soap not merely through the interracial gay couple David and Keith, but through the couple embodied by Nate and Brenda, see the articles by Joanna di Mattia, Brian Singleton and Samuel A. Chambers in Reading Six Feet Under: TV to Die For, ed. Kim Akass and Janet McCabe, London, I.B. Tauris, 2005, p. 149-190.

14 But in turn, later episodes of Six Feet Under seem to criticize $Q A F$ for being unrealistic about the after-effects of trauma. After being assaulted in 5.4 (an episode that was aired in 2004), David is crippled by panic attacks and haunted by nightmares almost into the finale (he confronts his demons in 5.11). Of course, David is a study in conflicted values and low self-worth, whereas Justin is the darling of $Q A F^{\circ}$ s inset gay and lesbian community and nicknamed "Sunshine" not merely for his blond hair, but for his embodying the opposite of melancholia.
} 
Justin also only slowly retrieves motor control of his hand, which endangers his future as an art student. Thanks to Brian, he will learn to draw again using a computer, in an interesting inset image of digital creation, in which all forms of art, as Michael J. Wolf puts it, are perhaps "various dialects of computerese $\mathrm{e}^{15}$ " - announcing the series' impending remediation, rather than spin-off, into other digital art forms. This dynamic surfaces in a Season 2 subplot, when Michael, who has become the owner of a comics book store, making his lifelong passion his job, discovers that his hero, Captain Astro, has been killed.

\section{Captain Astro: Killing the Gay Hero Again, in Comics Mode}

Episode 2.10 casts this fatal twist by immersing us in comic book mode ${ }^{16}$. Our gaze is sutured to Mikey's as he reads of Captain Astro's apparent victory over his arch-nemesis Morphisto: hand-held camera movements, sweeping across each frame in extreme close-up, diagonally, with zooms onto specific speech bubbles, with Mike's enthusiastic voice-over "performing" both Captain Astro's voice and his antagonist's, turn this into a "comics reading experience", short of turning into actual animated film (see Plate 5).

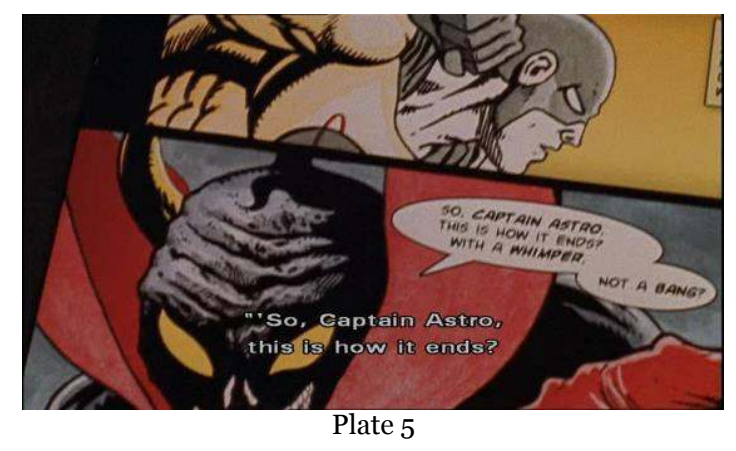

The camera only draws back to let us see, in countershot, Mikey's entranced face and his metatextual comments (see Plate 6).

15 Murray, p. 418, quoting Michael J. Wolf, The Entertainment Economy: How MegaMedia Forces Are Transforming Our Lives, London, Penguin, 2000, p. 92.

${ }^{16}$ Watch the clip on YouTube $:$ http://www.youtube.com/watch?v=BKZOJsl5uEw 


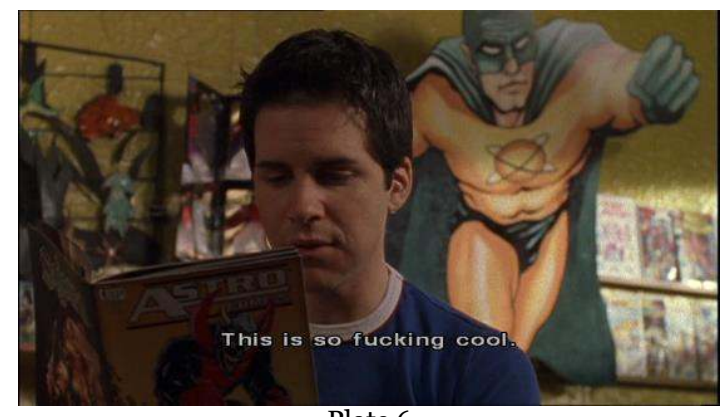

Plate 6

It comes as a brutal shock for Mikey and the viewers alike to discover in the very last frames that Morphisto has in fact lured Captain Astro onto a planet infected by a mortal virus that Morphisto is immune to. The allusion to AIDS is made all the clearer since according to some fans, the voice-over is not in Mikey's voice, but in his HIV-positive partner Ben's as Captain Astro helplessly cries out: "Help me". The words "the end", spoken by the villain (see Plate 7), and echoed by the second "THE END" in comic font (see Plate 8), mark not merely the end of a subplot or even of this comic book, but the final frame of the Captain Astro series as Captain Astro dies.

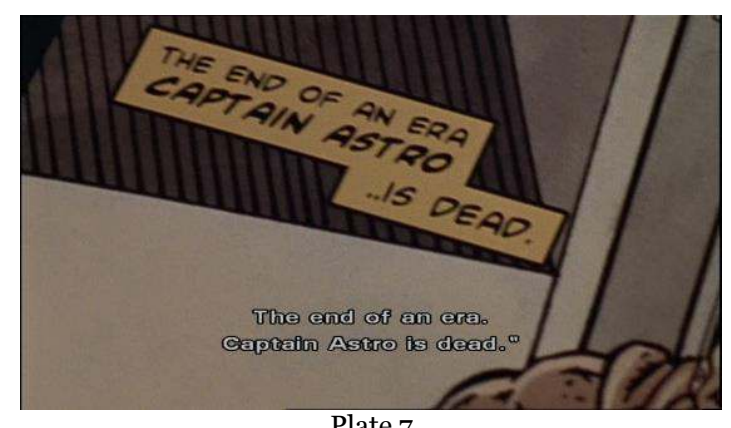

Plate 7 


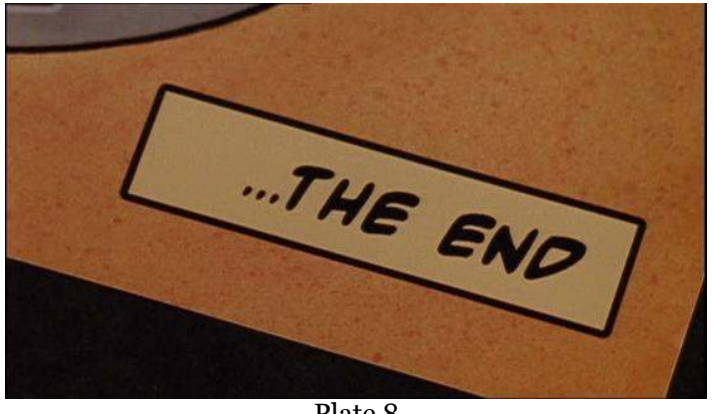

Plate 8

Although Captain Astro is a fictional invention of $Q A F$, it is made "real" through this brief sequence of irreversible loss. An accelerated zoom onto Michael's shocked face conveys the shattering impact of this discovery, as he incredulously echoes the last line of the entire comic series: "Captain Astro is dead!" (see Plate 9).

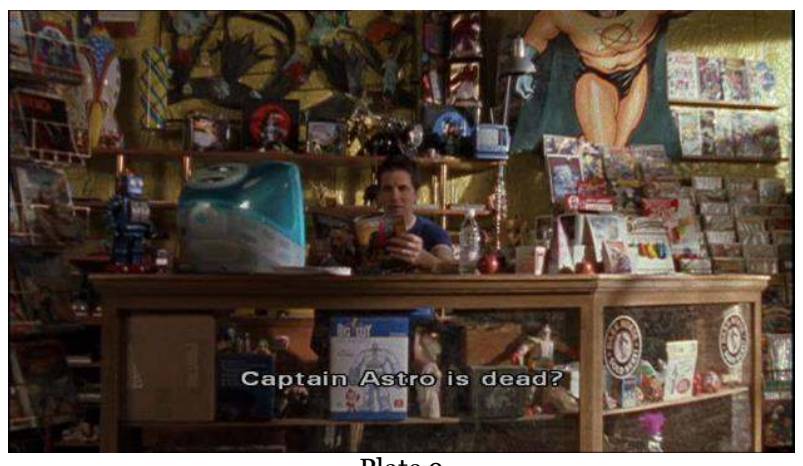

Plate 9

By cutting to the diner where Emmett answers this last cue as if there were no break in time-space continuity - "Oh my God, what happened?” (see Plate 10) - the screenwriters turn Captain Astro's death into a political symbol. 


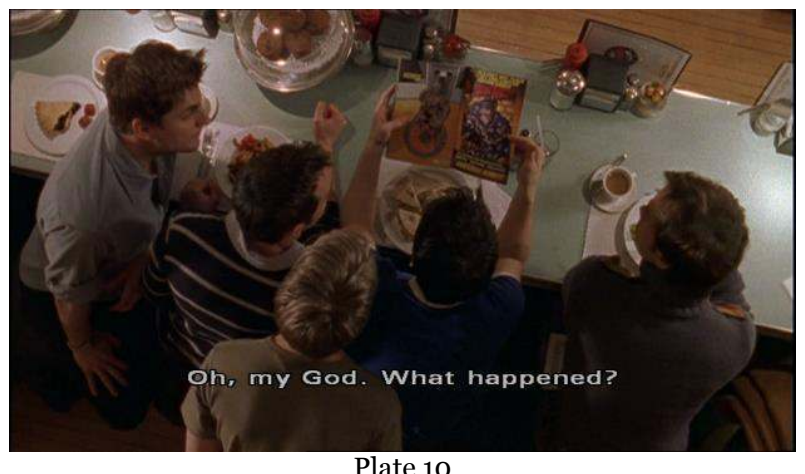

Plate 10

The choral conversation allows the unfolding of a number of ironies on narrative and commercial considerations always being meshed in any series (whether in comics or televised form) as Brian suggests that this "end" is probably a cliffhanger in disguise - "[it's] a cheap ploy to get you to buy the next issue" - in an echo of $Q A F^{\circ}$ s own previous ploy: hooking viewers into watching $Q A F$ s Season 2 in the hope that Justin would survive. The dialogue thus participates in blurring the lines between the "real" and the "fictional," via the inset "community of readers" now exchanging on gay or crypto-gay fiction, within the gay fiction itself. Captain Astro, while not explicitly gay, is understood by his gay fans to be so, since he has a younger male sidekick and no significant female other - as Brian quips, "well, after living with Galaxy Lad for thirty years, rumors were bound to circulate". The erotization of muscle ${ }^{17}$ (of hero and nemesis alike) in superhero comics, the hyperbolical and obsessional performance of masculinity, and the "partnering" of men (Batman and Robin, Captain Astro and Galaxy Lad) can of course be read through a queer lens. The homoerotic subtext of the hypermasculine world of superheroes has been perceived at least since the 1950s; Catwoman was specifically created as a love interest for Batman to counter rumors that he and Robin were a gay couple $^{18}$. The palimpsest of fictions in the series, while it opposes the sophistication of the series' universe of urban out gay characters to the

17 See Susan Jeffords, Hardbodies: Hollywood Masculinity in the Reagan Era, New Brunswick, Rutgers University Press, 1994.

18 See Zachary Snyderman, "Why Your Comics Are Getting Gayer", Esquire, June 1, 2013 , http://www.esquire.com/blogs/culture/gay-superheroes. See also Michael Bronksi, "Comic Relief", Phoenix.com, August 22-29, 2002, on how Fredric Wortham, in his 1953 bestseller Seduction of the Innocent, argued that comics were "perverting" boys into gay desires. http://www.bostonphoenix.com/boston/news_features/top/features/documents/024049 o7.htm 
crypto-gay teen universe of superheroes Mikey has remained fond of ${ }^{19}$ also plays on the idea of a gay continuum, and explicitly "teaches" its audience to read familiar comics as always-already queer.

The diner itself is the perfect setting for a debate on gay heroes: managed by Michael's mother Debbie, who systematically sports "I'm proud of my gay son" badges or T-shirts, it is a fictional space of gay community - just as Babylon, the nightclub favored by Brian, functions as both setting for, and symbol of, the hedonistic facets of gay culture ${ }^{20}$. The diner (or café, or bar) is of course one of the staple artifices of TV series, as a convenient set to shoot encounters, breakups, and especially, protracted conversations, from Happy Days (Garry Marshall, ABC, 1974-1984) to Melrose Place (Darren Starr, Fox, 19921999), and from Friends (David Crane and Marta Kauffman, NBC, 1994-2004) to The L Word (Ilene Chaiken, Showtime, 2004-2009). The irony of this scene is that fictional gay characters (the heroes of the series) discuss other fictional gay characters (the comics superhero Captain Astro). One might argue that we are briefly reminded, as we cut from the comics to the diner, that we are still in a fiction, since in the shot from above (see Plate 10), we see the group of friends' heads from an impossible height, greater than if we were merely standing, looking above their shoulders. Our screen functions as a window (in a denial of the fourth wall of the diner), all the more so if we are viewing $Q A F$ with friends, and if our living room is, de facto, a real-life extension of the diner. Beyond the gay banter about Captain Astro's demise - for instance, Emmett's quip about the captain still looking good in Spandex at his advanced age - the deeper emphasis in this scene is on the politics of representation: on Michael's taking fiction to heart as if it were reality (Debbie faults him for it) and on his reading a political meaning into his hero's death (Ted, the most conservative character, resists this). Through this mise en abyme - was Captain Astro terminated because he was perceived to be gay? And does this make his death a "hate crime", as Justin says? - the series can repeat the political question it wants to place center stage: how not to live in denial, and how to confront homophobic violence.

${ }_{19} \mathrm{He}$ is the only character to still be called by a childish diminutive (Ted is not called "Teddy" except by Emmett) and to be so defined by his status as a son. Until the very last episode, we know him to be (to some extent) living in the past of his unconsummated teenage love for Brian.

${ }^{20}$ Samuel A. Chambers views this as part of the series' not confronting heteronormativity (even as it confronts homophobia): "With Queer As Folk, then, it is not so much that there is no closet as that the show itself takes place within the closet." Samuel A. Chambers, "Telepistemology of the Closet," The Queer Politics of Television, London, I.B. Tauris, 2009, p. 36. 


\section{A Series of Hate Crimes, Echoing in Remediation}

Within this episode (2.10), Captain Astro's being "killed" (by the publishers) because he was gay comes not merely as an echo of Justin's near-fatal experience, but of a more recent hate crime: a young gay man has just been found dead in the diner dumpster. Hence, too, the fact that Debbie is angered that her son seems to care more about his (gay) hero's demise than about the "real-life" death of a gay young man $^{21}$. The ironies of the dialogue cut in many ways, perhaps testing the series' viewers: have they been indifferent both to the hate crime introduced in this episode and to the cynical comics nickname "Dumpster Boy" that the characters have been using for the victim, or have they resisted it empathetically? Beyond, we are asked to reflect upon representations: is not the existence of fiction that depicts gay heroes and gay superheroes intrinsically connected to the issue of gay visibility, gay rights, and empowerment ${ }^{22}$ ? See (Plate 11) for instance this December 2012 poster French associations used to encourage gay men to find out their HIV status, with the slogan "The Super Power to Test For AIDS!".

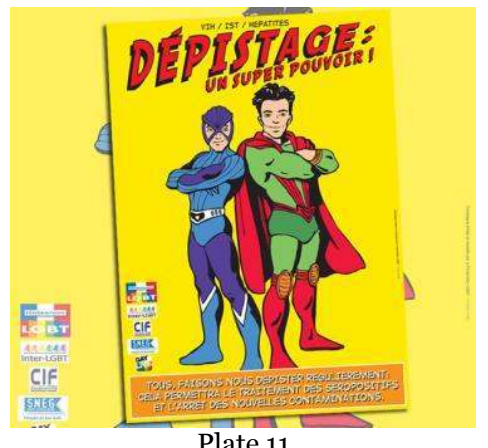

${ }^{21}$ The entire subplot about Mike and Ben adopting the young hustler Hunter could be seen as Mike's reluctantly coming to love an avatar of "Dumpster boy" whom he does contribute to save.

${ }^{22}$ See these studies of queer comics: Justin Hall, No Straight Lines: Four Decades of Queer Comics, Seattle, Fantagraphics, 2012, and Markus Pfalzgraf, Stripped: A Story of Gay Comics, Berlin, Bruno Gmünder Verlag, 2012. There is of course a long history of "adult" (pornographic) gay comics, from Tom of Finland to Iceman Blue (the latter recycles classic superheroes like Spiderman into gay porn). $Q A F$ plays on this in episode 3.9. Justin and Michael have just argued over the appropriateness of a sexually explicit cover for the next issue of their comic book Rage; when we see Brian and Justin having sex, they are clearly "reenacting” Justin's drawing that hangs above Brian's bed. Brian explicitly holds up the drawing as his erotic inspiration at the end of the sex scene. We are thus shown yet another form of (erotic) remediation. 
$Q A F$ unequivocally answers that gay heroes, gay storytelling and gay empowerment are indeed connected, by having Michael and Justin decide, in episode 2.15, to create a gay comic series that will replace Captain Astro. During a brainstorming sequence at Brian's loft, which amusingly plays on Justin's complete ignorance of the most famous comics' storylines - he naively pitches to Mikey ideas that already exist as Aquaman, Spiderman and Superman, suggesting either that these cultural products are so pervasive as to be ingrained in all American boys' deepest subconscious memories even when they do not know comics, or conversely, that as fiction, they are too predictable and "clichéd" -, Justin and Mikey suddenly focus on Brian, who is running, bare-chested, on his treadmill a dozen feet away. As the image zooms and accelerates to mimic their sudden inspiration, but also superheroic speed and strength, they simultaneously find the model for their character. In a riff off Superman, they make him a cynical ad executive by day, and avenger of Gayopolis by night; the comic book is to be named Rage, a pun on Brian's bad temper, but also on his trendiness "all the rage" - in a multilayered homage to Brian's (and the series') marketing savvy 23 .

As they struggle to find a plot for their first issue, Michael suggests that "Rage sav[e] a kid" from a gay-bashing, in a barely veiled allusion to the end of Season 1. Although he is sure Justin will reject the idea and apologizes for mentioning it at all, the younger man validates the plan, highlighting that it will give him a chance to tell his story, because like most trauma victims, he feels burdened by the fact that now that he has rebounded physically, "everyone pretends it didn't happen". While it seems this line could apply to viewers, each season will in fact feature a tragedy due to homophobia that reactivates the trauma of Season 1 for them, as much as for Justin. (In episode 4.3, for instance, Justin will join a "Pink Posse" that fights back using violence against homophobes ${ }^{24}$.) When Justin suggests Rage could, besides, find "the love of his life" by rescuing this gay boy, whose name in the comic script will be J.T. - Justin's own initials -, he explicitly connects the soap and political narrative threads of Rage the way the Season 1

\footnotetext{
23 Brian puns on his own name, Kinney, when he founds his own advertising company, Kinnetik, a brand/term which can obviously function as a metaphor for transmedia storytelling too. One notices that Brian, like Don Draper in Mad Men (Matthew Weiner, AMC, 2007- ) and as an ad man, is not merely an economically powerful figure, but an inset figure of the (disguised, masked or elusive) storyteller. Like Don, he uses his real life, remediating it into his ads. See Rebecca Clare Beirne's analysis of Brian's "Eat the Meat" ad, and others in "Embattled Sex: Rise of the Right and Victory of the Queer in Queer As Folk", in The New Queer Aesthetic on Television, ed. James R. Keller and Leslie Stratyner, Jefferson (NC), McFarland, 2006, p. 49-51 in particular.

${ }^{24}$ This may also be a wink to the way the British $Q A F$ ended, in a flight into western-like fantasy after a "counter-homophobic" form of violence on Stuart's part that entails fleeing from the police.
} 
finale did for us. As Mikey and Justin speak, in episode 2.15, the background display of the numerous superhero comics Michael sells, from Ironman to Spiderman, allows the creators of $Q A F$ not merely to include their creation within superhero culture, but also to emphasize the always-already gay aspects of "traditional" comics superhero culture $^{25}$

\section{Cathartic Remediation}

The series starts to play on echoing through intermediality, and takes its remediation of comics into film and/or of the series into comics to the next stage, later in the same episode. Indeed, in the closing moments, we see Brian's entire loft saturated with single frames hanging on clotheslines (see Plate 12), in a figuration of comics' "spatialization" of drawings as opposed to the series' filmic aesthetics ${ }^{26}$.

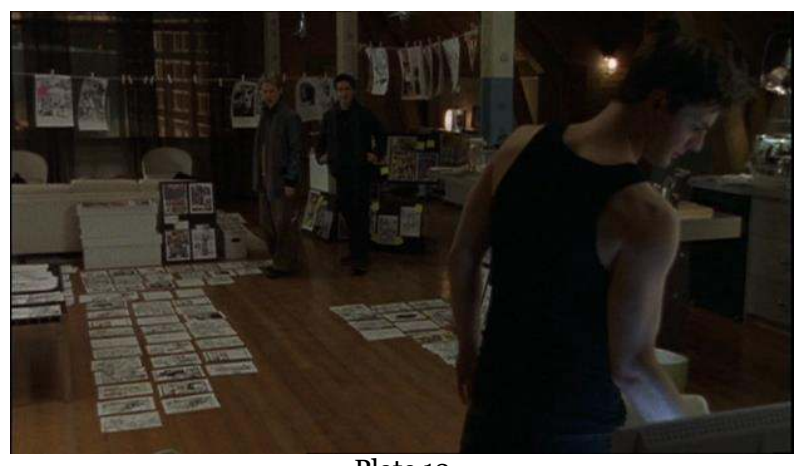

Plate 12

This can, of course, also be seen as a wink to the storyboard behind the TV series, and a reminder that before Michael, Brian or Justin were played by actors in the flesh, they were figures drawn into frames. When Brian half-jokingly comments on the stereotype of the square-

${ }^{25}$ On a more subtle "queering of the canon" and on $Q A F$ s deliberate queering of the interpenetration of highbrow and popular culture, read Ronan Ludot-Vlasak, "Canon Trouble: Intertextuality and Subversion in Queer As Folk", TV/Series, No. 2, 2012 (TV Series in the World: Exchanging Places, Places of Exchange, ed. Sylvaine Bataille and Sarah Hatchuel):

http://www.univ-lehavre.fr/ulh_services/Numero-2-Issue-2-novembre-2012.html

26 "Isn't animated film just visual art in sequence? [...] [T] he basic difference is that animation is sequential in time but not spatially juxtaposed as comics are. Each successive frame of a movie is projected on exactly the same space... the screen... While each frame of comics must occupy a different space. Space does for comics what time does for film." Scott McCloud, Understanding Comics, New York, Harper Perennial, 1994 [1993], p. 7. 
jawed hero and the need for his avatar's jaw to be "built up" (see Plate 13), he draws our attention to the clichéd element of comics, versus the "realism" of the TV series.

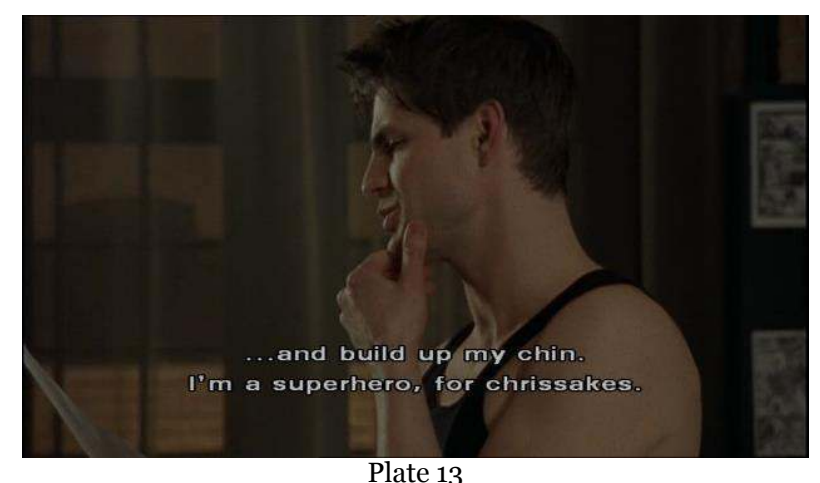

Indeed, as he gazes at a frame of himself as Rage, dance floor music starts to drown out the other characters' voices, and the comic turns to animated film: Brian's fantasy of flying to Babylon (see Plate 14).

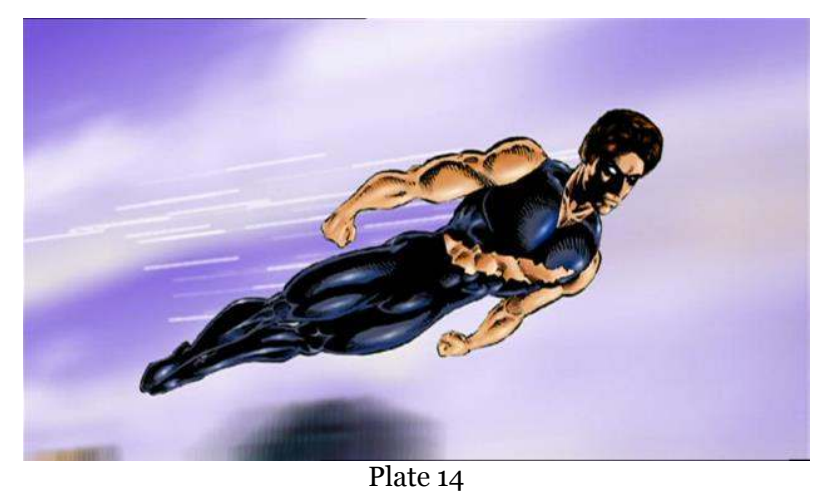

The fact that the episode closes without a return to the "frame" of the series itself, as the screen fades to black on this image of Rage landing on the roof of Babylon (seen in inverted writing, either as a pun on "inverts", or, more likely, as a graphic inscription of the behind-thescenes aspect of this episode), marks the beginning of moves blurring the borders between $Q A F$ and Rage in metalepsis (see Plate 15). 


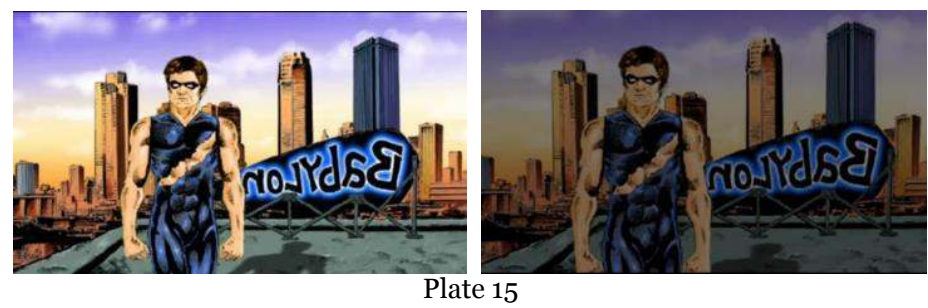

\section{From the comic strip to the floor show}

Episode 2.20, the Season 2 finale, literally opens on the opening of the boxes holding the first copies of the comic strip: an image of the frames within the frames, or story within the story, that Rage represents. The metatextual cues exchanged between Mikey and Justin about a story that was once simply a fantasy or dream in the creator's mind now being shared with an audience apply, beyond the inset comic book, to the series as a whole. No doubt $Q A F$ s producers must have toyed with the idea of turning $Q A F$ into a transmedia storytelling franchise of the type developed by Heroes; but Rage as a separate (spin-off, or tie-in) fiction never took off. Although $Q A F$ did not or could not turn Rage into a money-making machine as part of a crosspromotional marketing strategy in which the comics extends the series within what M. J. Clarke calls "tentpole television'27", it is interesting to note that the final episode of this season, in which Brian organizes a grandiose launch for Rage at Babylon, was in fact the most expensive episode of the series to date, perhaps proof that the promotion of extended storytelling was indeed considered an investment by the producers $^{28}$.

The launch party starts with a remediation of Rage into a floor show: the opening of Rage (itself a re-telling of the gay-bashing we witnessed in Season 1) is thus reenacted on stage. The visual work in this episode - the use of gigantic laser beams, of a huge cardboard cutout of Rage emphasized by high- and low-angle shots (see Plate 16) - reflects the marketing genius Brian is credited for within the diegesis: naming cocktails for the characters, getting the dancers to wear masks and turning Babylon into Gayopolis itself.

\footnotetext{
27 See M. J. Clarke, Transmedia Television: New Trends in Network Serial Production, London, Bloomsbury, 2013.

${ }^{28}$ See the short documentary on the making of this episode: "The Making of Rage Gay Crusader part 1":
}

http://www.youtube.com/watch?v=PZHL6Za2SLQ 


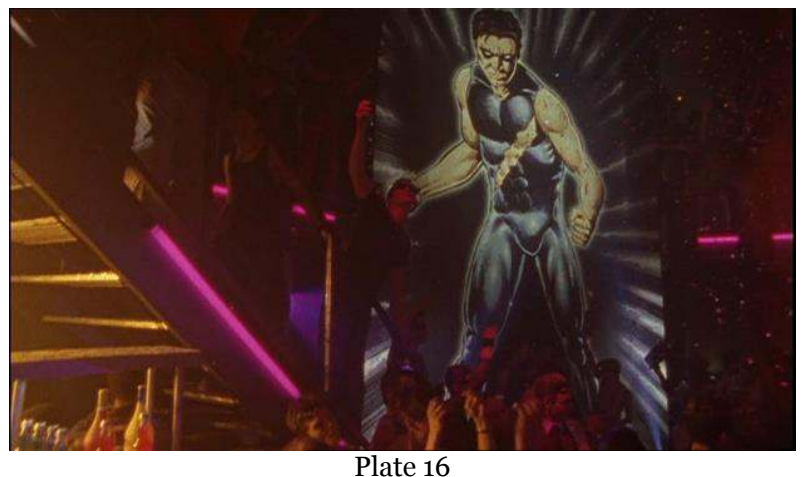

Plate 16

We have already witnessed a number of Babylon floor shows, always introduced by a host whose inset camp performance enhances the "hyper-masculinity" staged by the shows themselves (see the "Best Chest" contest, episode 2.15). Here, the host's clichéd, deep-voiced, suspenseful voice-over (one that film viewers associate with straight superhero film trailers), is queered by introducing a superheroically sexual component. The "normal" hyperbolic beginning of the voiceover - "With powers of mind greater than any known to man, he can bend anyone's will to his, rout the forces of intolerance and injustice" ends with the queer twist: "and still have the strength to fuck a hundred guys..."

As we watch the show, however, the focus shifts from camp excess to the reenactment of the Season 1 gay-bashing. There is significantly a reverse shot on Justin looking on as his story is replayed in theatrical form, while he stands surrounded by a sympathetic inset audience, to emphasize the therapeutic value of this reprisal for him. The hyper-flamboyant entrance of Rage and Zephyr, lit up by fireworks and floodlights and elevated to the stage from below (see Plate 17), in a symbolic elevation to the status of community superheroes, marks the birth of the gay superhero - of course, neither the actor playing Rage nor that playing J.T. are as handsome as their supposedly "real-life" counterparts, so as not to upstage the series' leading men, as embodied by Gale Harold and Randy Harrison. 


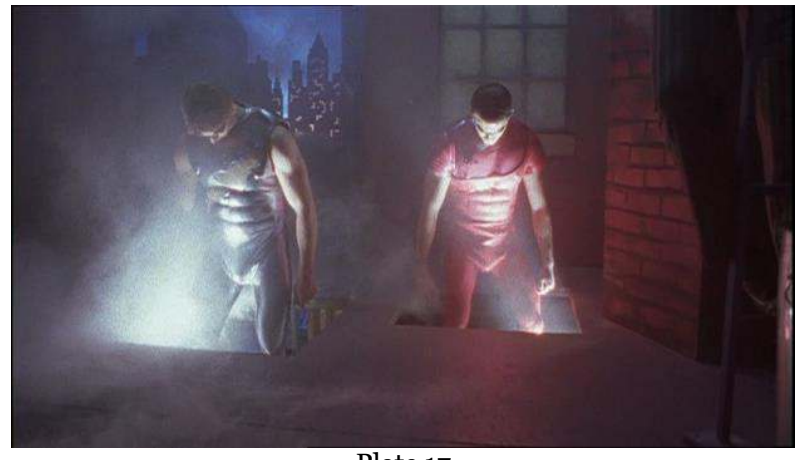

Plate 17

In this variation on Justin's traumatic experience, not only does Rage rout the homophobes, but, in a parody of sci-fi and comic universes, he catches them in a "mind distortion field" that causes them to mistake each other for gays and beat each other up (see Plate 18).

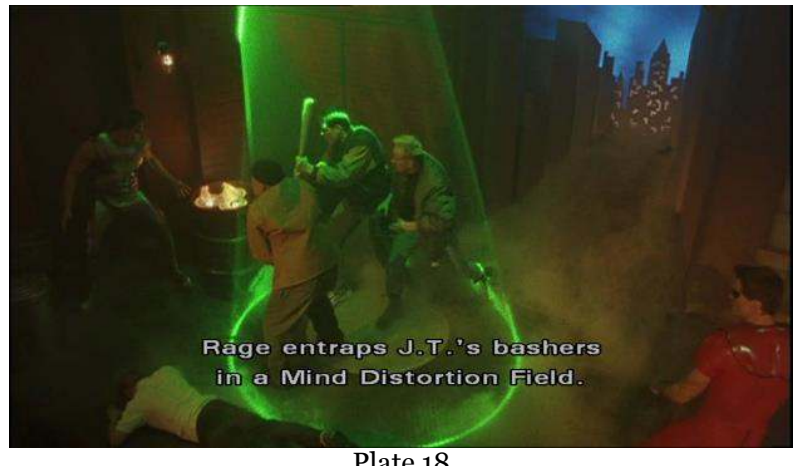

Plate 18

Then, as the light turns to blue (for same-sex masculine seduction), Rage uses his "other" superpower in a gender-bending version of Sleeping Beauty ${ }^{29}$ : as J.T. is revived, geysers of light shoot up in the background, in a suggestive Esther Williams-like choreography. The prolonged kiss which the crowd cheers provides a fairy-tale rewriting of the actual scene witnessed in Season 1, since Justin's coma, and Brian's cry of anguish, are all edited out here, the show (and the comic book) being a re-articulation of trauma into a controlled narrative. As the host concludes the show with the moral "Justice prevails in Gayopolis", the gap between the show and the diegetic world of the series (in which

29 Those familiar with Matthew Bourne's all-male ballet production of Swan Lake might see this Romantic dimension as echoing Bourne's. 
no justice has been served for the boy found in the dumpster) is heightened, reminding us that Rage is a form of fantasy-fulfillment. The gap between the inset text acted out onstage (the love between Rage and J.T.) and the cliffhanger Season 2 is about to end on (Justin leaves Brian for a violinist who promises monogamous romantic love), also points to dramatic irony; as for "Gayopolis", gay viewers of course see it for what it is - a utopia ${ }^{30}$.

\section{Rage as Film? From the Series and Comics to the Storyboard, and to Animated Film}

These ironies as to the "real" world of the series are taken to another level when we learn, in episode 4.6, that a famous film director, Brett Keller, wants to turn Rage into an action film. Justin, who has returned to Brian, now leaves for Hollywood where we find him at the opening of Season 5. The first two minutes of the season are an immersion into the Rage storyboard (see Plate 19).

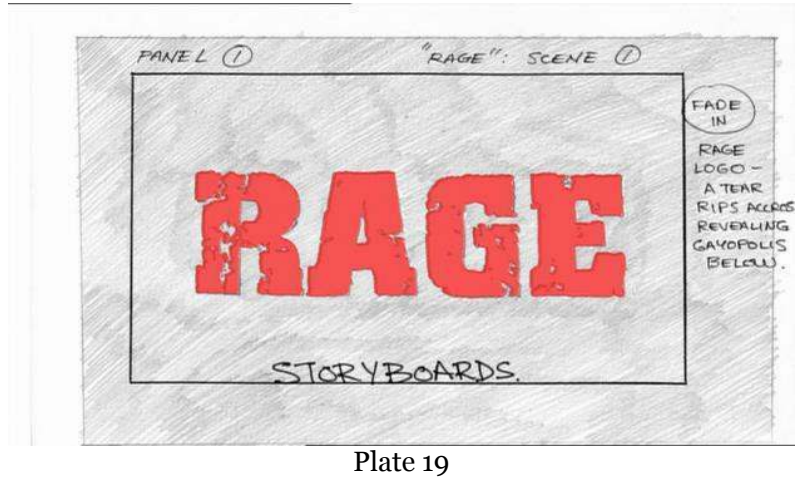

The voice-over seems that of a film trailer, while an acceleration of colors (red, orange, blue, green, purple) mimics the rainbow flag, before the title, RAGE, appears center screen, within a storyboard's first frame (the caption above the frame reads: "Panel 1", "Rage Scene 1 "). The font is that of comics but the script is ready for the remediation into film, with the shooting indications "FADE IN" and "A TEAR RIPS ACCROS REVEALING GAYOPOLIS BELOW". The spelling mistake on "across", spelled with two "c"s and only one "s", reinforces the feeling that we are seeing an artist's rough work in progress. Each frame has a typed fax date as a "reality effect" that increases the feeling of authenticity: "Oct. 21, 2004" for Frame 4 showing the fly-over view of Gayopolis (see Plate

${ }^{30}$ It is also a fictional reconfiguration of Pittsburgh's Liberty Avenue in the series' diegesis (which is, in reality, not shot on location, but in Toronto). 
20). The camera zooms in and we start to "enter" the landscape, but are pulled into the frame showing Rage and Zephyr "trying to escape the land of the clones".

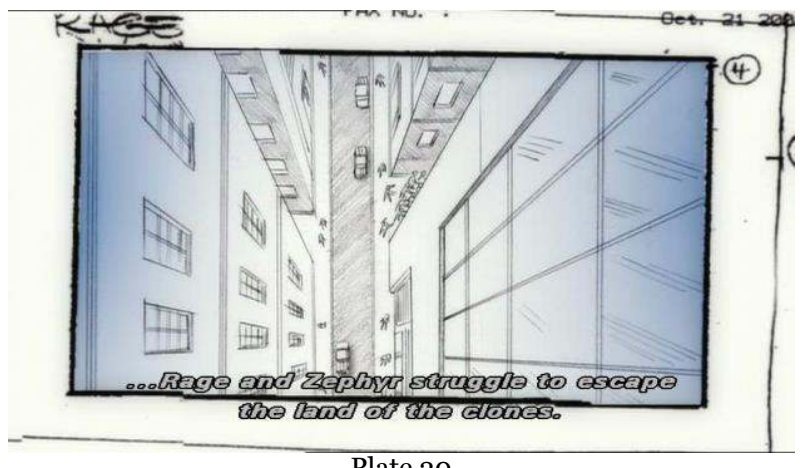

Plate 20

The ironic viewer will immediately realize that the references to the "undead" that live at night and to the "land of the clones" are a jab at gay culture ${ }^{31}$. As the camera zooms in a performance of the "PUSH IN" directions (drawn as arrows in the storyboard, see Plate 21), the image morphs from drawing to the aesthetics of a pop-up book in which the various drawn silhouettes appear in $3-\mathrm{D}$. Then, the exact same frame morphs into film, as the "clones" become the party boys who haunt Babylon, and in whose midst we glimpse Brian and Mikey dancing (see Plates 22 and 23).

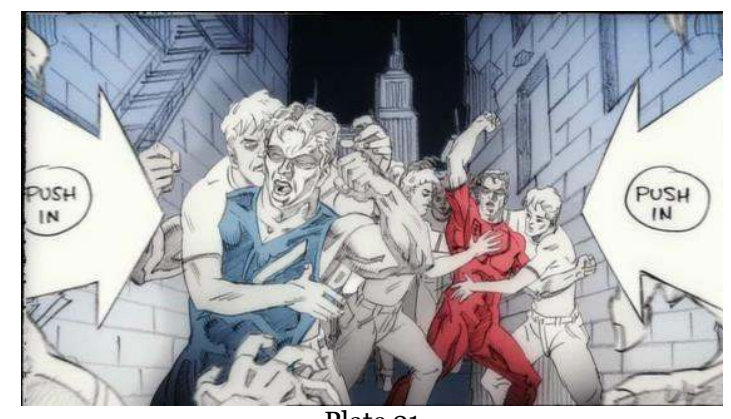

Plate 21

${ }^{31}$ Specifically, at the supposed normativity of gay male subculture, leading to "cloned" looks and recognizable "identities" within determined groups ("Twinks", "Gym Queens", "Bears", etc.) 

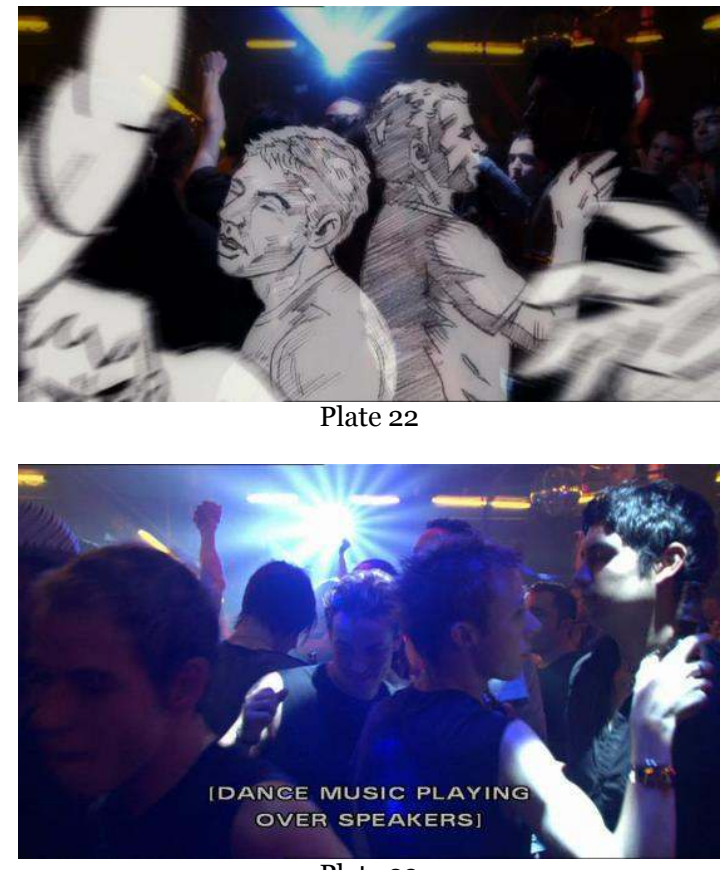

Plate 23

The dialogue makes the "convergence" of the storyboard and series texts clear32.

MiKEY. Inside [here] nothing ever changes. Everything's the same. Same hot guys, same thumpa-thumpa ${ }^{33}$, same-shaped chest..

BRIAN. And what a comfort it is to know.

MIKEY. It's all a lie, an illusion, cheap theatrics...

BRIAN. Nevertheless, let's keep dancing...

As Mikey utters the words "nothing ever changes", the frame around them freezes, while they continue to move34, recreating the "pop-up" effect of the storyboard for everything that surrounds them (see Plate 24). This sudden exposure of artifice - if all around Mikey and Brian is film, are they not, too, simply fictional characters, speaking of the

${ }^{32}$ It is to be noted that McCloud attempted a form of webcomics that abolishes this difference, by treating the screen as a window one zooms into indefinitely, for each new frame to appear: the "infinite canvas" style. See his website (and his webcomic The Right Number for instance): http://www.scottmccloud.com/1-webcomics/index.html

33 Thumpa-thumpa is Mikey's onomatopoeia for house music (a reference to its beat)

34 A technique used, also for purposes of de-realization, in Cameron Crowe's Vanilla Sky

(2001). 
fictionality of the landscape they inhabit? -, instead of destroying the illusion, paradoxically preserves it.

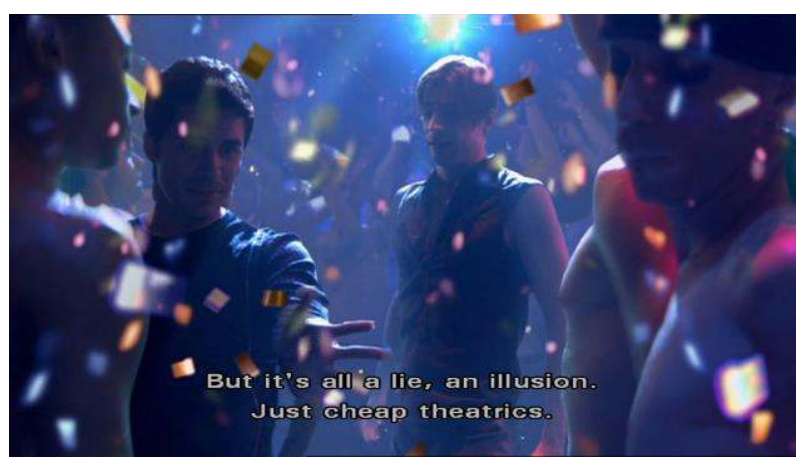

Plate 24

The multiple levels of exposed artifice, when Michael brushes away the glitter that falls from the invisible fourth wall standing between him and us, pointing to his being caught in a reality on that side of the screen, should de-realize all the levels of storytelling - the series, the comic strip and the inset storyboard. But instead, each peeling away of artifice reinforces the overall fictional illusion35; within remediation, each construct mirrors the other, reanimates it, revitalizes it, prompting us to deny what has been revealed, even before we have a diegetic explanation for this "vision" (Brian and Michael are actually "high" on party drugs). While one tends to associate these forms of flaunted artifice with highbrow forms of culture (from theater to postmodern novelistic writing), ever since Sex \& The City (Darren Star, HBO, 1998-2004), narratively sophisticated series have played on the use of mise en abyme, metalepsis, direct address to the viewer, through voice-over and sometimes through direct address to the camera, as Kevin Spacey does in Netflix's reboot of House of Cards (2013). Just as readers of popular postmodern authors like Jasper Fforde can enjoy both the story itself and the uses of metafictionality, deconstruction, ironic intertext and constant metalepsis, so viewers of series that constantly reference their own functioning stay caught within the story even as they enjoy moments when the creators, screenwriters or artists show their hand.

35 Another form of mise en abyme is to be found in series that play on documentaries being shot within the fiction, and the tension between being taken "behind the scenes" or showing the fiction as a construct. For a fascinating analysis of these reflexive phenomena, see Julie Levin Russo. "Inside the Box: Accessing Self-Reflexive Television", The Journal of e-media Studies, Vol. 2, No. 1, 2009, Dartmouth U.:

http://journals.dartmouth.edu/cgi-bin/WebObjects/Journals.woa/1/xmlpage/4/article/324 
At the eighteenth minute of the same episode, the series again plays on the reflexive echoes between its storyline and what develops in Rage. In Season 4, Police Chief Stockwell is campaigning for homophobic proposition 14, causing Liberty Avenue to mobilize against him. In the inset remediation into comics, the voice-over we have already heard now introduces us to Stockwell's avatar, Reverend Swineheart, Rage's arch-nemesis, literally represented as monstrously half-hog (see Plate 25). This time the camera immerses us in the storyboard frames, before zooming out, and displaying, through captions, the technical terms for the animated film unfolding before our eyes.

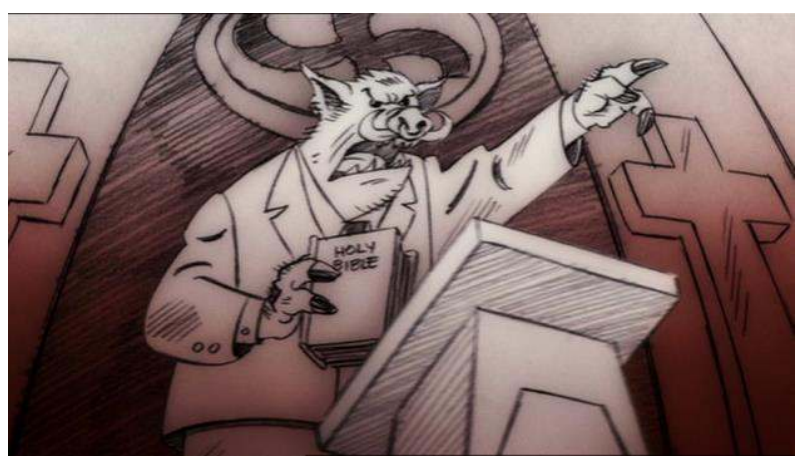

Plate 25

For instance, the transition from a subjective view of fire filling the frame, to Rage hanging by his feet above this fire in the catacombs is entitled: USE THE FIRE WIPE FROM PREV. SCENE, teaching viewers the term "wipe" for this dynamic filmic technique. This time we notice an overlay of manuscript (comic font) and of typed indications, the typographical palimpsest acting as a reminder of the layers of remediation in these short sequences (see Plate 26). 


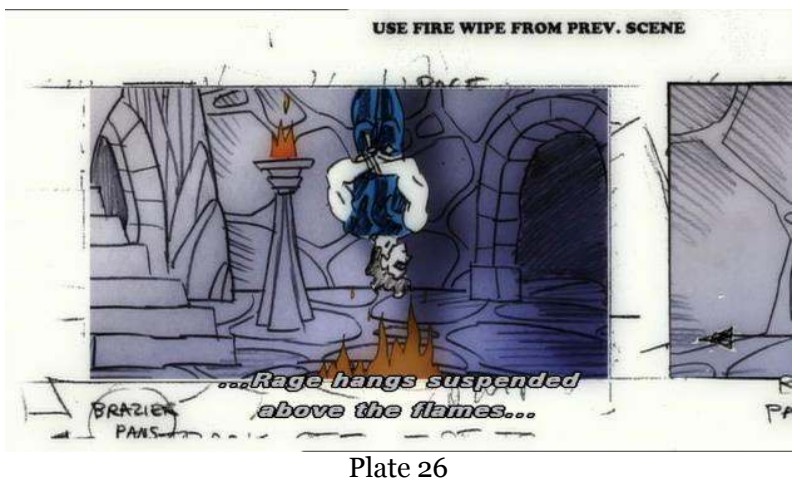

While the voice-over is conventionally dramatic, the line "Rage hangs, suspended above the flames, his hands bound in really hot leather restraints" again allows queering through sexual innuendo, bringing to the fore the erotic dimension of comics violence, simply by adopting an explicitly gay perspective. Again, the storyboard comes to life as the main character moves against a backdrop of static figures and landscapes, turning the drawing into a form of pop-up animation (see Plates 27 and 28) and finally into film, as J.T. morphs back into Justinthe-artist as he writes/draws ${ }^{36}$ the entire sequence, in a play on multiple levels of fictionalization, inset storytelling and changes of medium (see Plate 29).

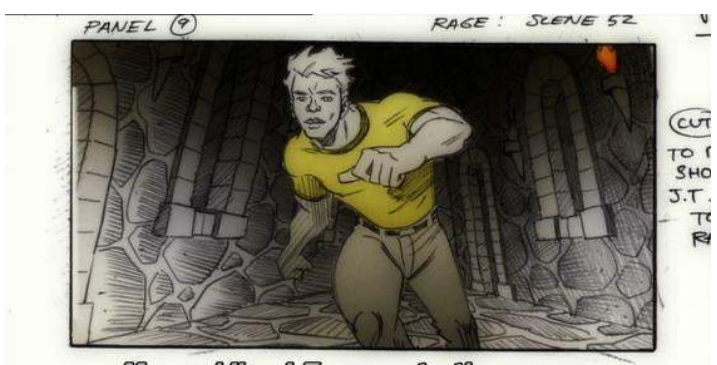

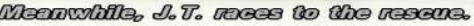

Plate 27

${ }^{36}$ When Justin says that he hopes that his hand will hold out, there is a direct reminder of the lingering after-effects of the Season 1 gay-bashing. 


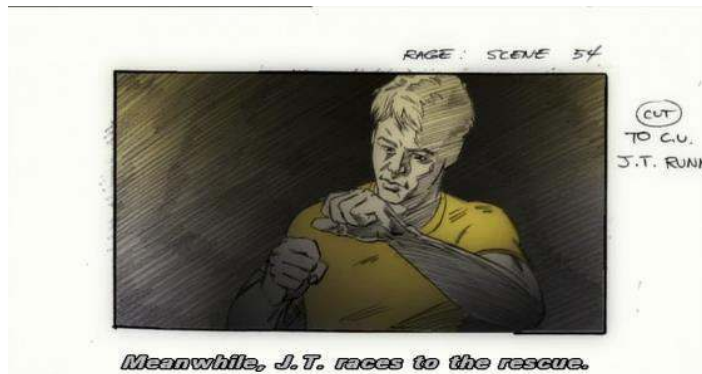

Plate 28

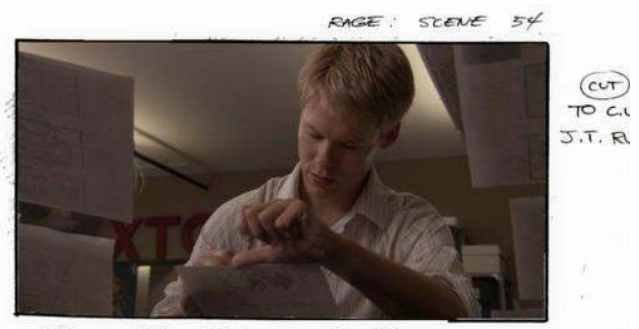

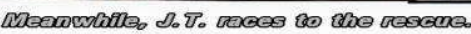

Plate 29

$\mathrm{He}$ is interrupted in his work by the film director, Keller, announcing with a flourish that he has just signed up a Hollywood star to play Rage: in walks Connor, the actor who had previously turned down the part for fear of compromising his career. The satire of the Hollywood world in which a star known by insiders to be gay must pretend that he is a "straight guy playing gay for pay" (as Connor phrases it), rather than come out of the celluloid closet 37 , is underlined by the prominence, in the background, of a poster of a masked Rage, the mask being a sign of the star's "disguised" sexual identity. The schizophrenia of male action stars having to hide that they are gay is again emphasized in episode 5.1. As we move from a reveal of an animated version of J.T. floating "among the stars" (see Plate 30) - a pun on Justin's being in Hollywood, as much as his being separated from Rage/Brian - to a morph back to Justin, busy at work on the storyboard, a voice is heard seemingly spoken by the fictional Rage: "I told you I'd come for you, J.T., even if I had to go to the end of the universe."

${ }_{37}$ To quote the title of Rob Epstein and Jeffrey Friedman's 1995 documentary on the history of (often hidden-in-plain-view) depictions of gays and lesbians in American film. The film is based on Vito Russo's 1981 book. 


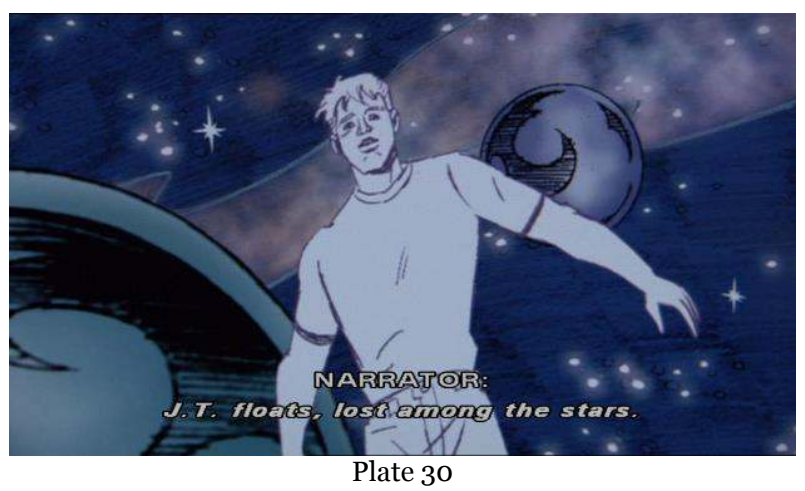

Connor, masked and costumed as Rage, then appears. The life-sized poster of Rage behind him reminds us that, like cinema, a series needs to be embodied before being "disembodied" again in projection on screen; and that, in the process, someone has to wear the sexy ${ }^{38}$ but "itchy" suit, to paraphrase Connor's complaint (see Plate 31).

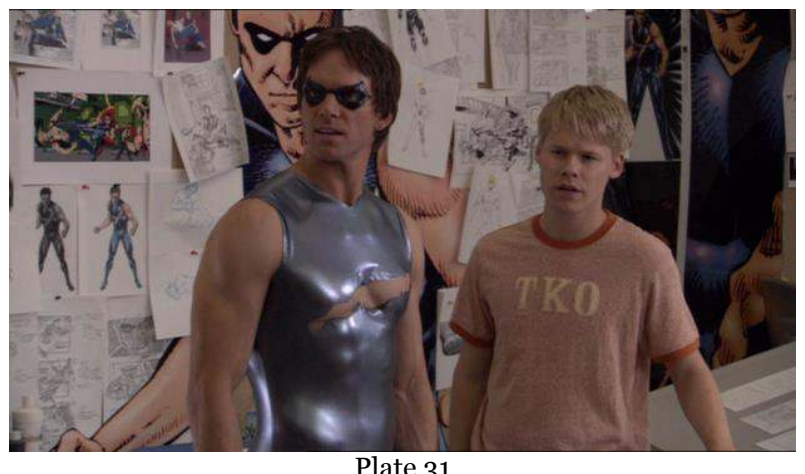

\section{Killing the Film and Ending the Series}

The climax of the scene, however, is the announcement there will be no film after all; that the studio - RTO, a spoof on RKO - has canceled the entire project. In the slightly heavy-handed dialogue that

$3^{8}$ Justin's jab that the anatomically revealing tights will earn an award for "special effects" and Connor's rejoinder "I didn't hear you complaining" are part of the post-sex banter that emphasizes that Connor is indeed gay; but they also function as a satire of "normal" superheroes' bizarrely modest "sprayed on" clothing which, while showing each ripple of muscle, paradoxically "veils" their crotch. Strictly speaking, of course, the entire superhero is a phallic "hardbody" in the sense theorized by Susan Jeffords. 
follows, one understands that the film was going to be sexually explicit and that the producer has suddenly got cold feet, because of "the times, the political climate", as the angry film director puts it. When Justin exclaims "But there are millions of gays out there with billions of dollars", highlighting the economic rationale for making gay films, he of course speaks for the audience of $Q A F$. The reason why there are, pink dollars notwithstanding, no gay action heroes in Hollywood cinema is then given - studios would rather forgo this market than risk "alienating the family audience, pissing off the parent corporation, displeasing someone in Washington who can make that tax break very hard to come by39".

When Justin voices our own incredulity: "So it's over? Just like that?" at a situation that echoes the heteronormative corporate killing of Captain Astro, the director's political answer perhaps masks the real reason for $Q A F$ s having to abort the film-within-the-series - not having the budget for it, probably. The political message is, however, clearly driven home: the quip "Gays are out, God is in", which reflects pessimism as to gay rights just after George W. Bush's 2004 reelection ${ }^{40}$, ironically echoes Rage's own storyline. Indeed, Reverend Swineheart's apparent victory over Rage as the storyboard is interrupted turns out to be a subtle heralding of events about to unfold within the $Q A F$ storyline. Fire literally erupts in Brian's own "church", Babylon, when homophobes place a bomb in it in episode $5.10^{41}$.

The bombing is the final, escalated replica of the Season 1 gaybashing: 7 die, and 67 are wounded, including major characters. In the last minutes of the final episode, Mikey and Brian return to the bombed-out, devastated shell of Babylon (see Plate 32). When Mikey is reminded by Brian of how he had quipped that life inside Babylon was "just an illusion" and how inside it, things never changed, he now reverses the statement to "some things aren't meant to change", in an explicit recognition of Babylon as eternal/utopian space, and invites Brian to dance with him. When asked what the music might be, since all the sound equipment has been destroyed, Mikey replies "our song,

39 This echoes how politics were playing out in Hollywood film that year (2004), in another field: the representations of the Bush administration, and of the war in Iraq. When Disney, Miramax's parent company, suddenly announced that it would not release Michael Moore's Fahrenheit 911 (which went on to be distributed by the Weinstein Brothers and to win the Palme d'Or in Cannes), for fear of displeasing George W. Bush, many surmised it was specifically for fear of losing the tax breaks for its Disneyworld Park in Orlando, Florida, a state Jeb Bush was Governor of then.

$4^{40}$ Anti-gay marriage laws put on the ballot in eleven states were instrumental in getting out the vote of some 2.5 million evangelical Christians who had not voted in the 2000 Presidential election, angered at the fact that VP candidate Cheney had appeared at the 2000 Republican Convention with his lesbian daughter (who, in 2004, was not invited onstage).

${ }^{41}$ Only when he sees Justin emerging from the rubble does Brian say, for the first time in five years, the three words - I love you - viewers had given up hoping for, bringing the political and soap elements of the series together exactly as the Season 1 finale had. 
of course", in a use of the pronoun that includes us, as viewers, beyond the blasted fourth wall.

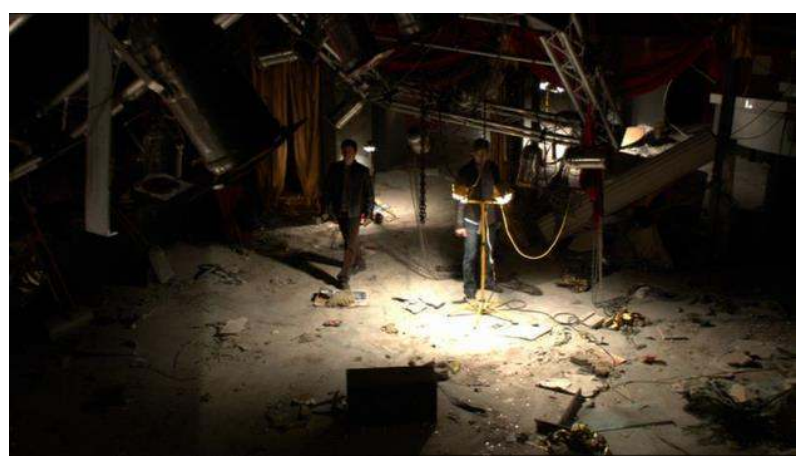

Plate 32

We then hear, increasingly clearly, the first beats of Heather Small's "Proud", as the two boys begin to dance in a defiant gesture of survival ${ }^{42}$ - until the sound reaches dance floor volume, and the pan movements accelerate, as if in a rush of life itself. The first words of the song are perfectly reflexive of the scene, both metafilmically and politically:

I look into the window of my mind -
Reflections of the fears I left behind...
I step out of the ordinary;
I can feel my soul ascending;
I'm on my way, can't stop me now,
And you can do the same -
What have you done today
To make you feel proud?

For as we look into the "window" of the screen, all that was absent, as emphasized by Brian's earlier quip to Michael, upon his shocked discovery of the bombed-out ruins - "What did you expect? Dancing boys? Glitter from above?" - comes to life again.

${ }^{42}$ Mikey's last words in the voice-over that closes the series are: "So the thumpa-thumpa goes on. It always will. No matter what happens, no matter who is president. As Our Lady of Disco, the divine Ms. Gloria Gaynor, has always sung to us, we will survive". 


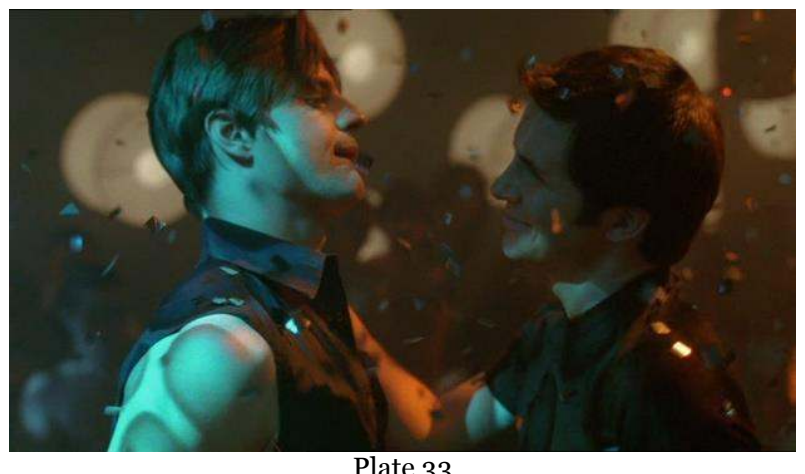

In a series of magical visuals, the glitter, as well as the laser beams, the dancing crowd, the tinkling of glasses all return, as the two men dance to the music (see Plate 33). While reminding us that Babylon was always a figment of the imagination and that, beyond Babylon, the series $Q A F$, with all of its remediated inset stories, is a world created by our collective fantasies, from its creators to its viewers, the last images resurrect the free and festive, the euphoric and proud moments of the past five years of stories told in multiple forms.

As if the counterclockwise accelerated movement of the camera around Brian (alternated with the slow-motion effects for emotion) were a rewind back to the past, we gaze onto Mikey and Ben, and the other couples we have come to know, dancing together, in a final echo of all that we have lived throughout these five years of "shared stories" with this cast of characters. As they reappear on the inset stage of Babylon-as-it-was, for us to be reunited with them one last time before we let them go, the series prepares us for what lies ahead; not within the series as it fades to black on Brian's solo dancing, but in the real world that we are returned to. For as the song "Proud" claims, some things need to change, and only we, the viewers, can be the agents of that change whereby gay-bashing and homophobia, closeted movie stars and the absence of gay heroes in action film, in comics and even in TV series shall some day have to be explained by footnotes, so strange will they seem to future generations 43 . By reprising, in its last

43 It is to be noted that, while there are now gay characters in a great number of series currently broadcast on networks and cable TV in the USA, there is currently no equivalent of $Q A F$. The short-lived Noah's Arc (Patrik-Ian Polk, LOGO, 2005-2006), which told the lives of four black gay men living in Los Angeles corrected $Q A F^{\circ}$ s almost exclusively white representations but, despite its success, was pulled by the network. While one might argue that today's Glee (Ryan Murphy, Fox, 2009-) or True Blood (Alan Ball, HBO, 2008-) are inherently queer, and aim to queer both the musical and the vampire series genres, there is not a single gay or lesbian-themed soap opera either on HBO or Showtime. Whether Jenji 
seconds, the happiest collective moments in the five-year storyline, the series ends on a celebration of resistance rather than fear, of community rather than destruction, of ongoing stories - within and outside the box 44 - rather than of endings, as, in an ultimate echo of Season 1's finale, Brian saves the last dance for Justin.

The series of remediations and reprisals comes full circle too. This last scene, with its use of inner echoing, exhibiting of narrative construction and of the audio, visual, and musical strands of storytelling that come together to "rewind" the series as it ends, reminds us that Queer As Folk is a proud fictional construct as well as a cultural product and an ideological vehicle for mainstream (middleclass, white) gay politics and gay representations. Whether or not the subplot of remediation of Justin's gay-bashing, from Season 1 onwards, was motivated by the desire to create a cash machine out of a spin-off comic book ${ }^{45}$, the fact that Rage did not survive in the real world can be seen as resonating with the series' political discourse on the persisting celluloid closet, for heroes and superheroes alike ${ }^{46}$. That the gay-bashing subplot, so fundamental to the series' love story and to its queering of soap, also creates a narrative arc that cuts through all five seasons and, in particular, structures three season finales, playing a pivotal role in the seriality of the series itself, underlines the idea that recurrence is not static repetition, but the creation of layers of narrative and of narrative depth. The remediation of Queer As Folk into a floor show, a comic book, and a storyboard is a narrative pleasure in itself that of immersion in "self-conscious media47" and in the hybridity of media - in a "queering" of form that subtly reinforces the series' identity.

Kohan's Orange is the New Black (Netflix, 2013-) will spark a return of such narratives remains to be seen.

44 Maine, Maryland and the state of Washington just became the first three states of the USA to legalize gay marriage by popular vote, on November 6, 2012.

45 As a scholar like M.J. Clarke would no doubt argue. The first (and sole) issue of Rage Gay Crusader was published by Red Cape Comics in 2002

46 Of course, the series has other, non-corporate extensions, through fan fiction or "slash" vidding. See Kyra Hunting, "Queer As Folk and the Trouble with Slash", TWC (Transformative Works and Cultures), Vol. 11, 2012:

http://journal.transformativeworks.org/index.php/twc/article/view/415/315

47 David Thorburn and Henry Jenkins (ed.), Rethinking Media Change: The Aesthetics of Transition, Cambridge, Massachusetts, MIT Press, 2004 [2003], p. 4. For a powerful essay on "self-conscious media" and remediation from Gutenberg to the digital age, read David Thorburn and Henry Jenkins, "Introduction”, in Thorburn and Jenkins, p. 1-16. 


\section{Bibliography}

AKass Kim and Janet McCABE (ed.), Reading Six Feet Under: TV to Die For, London, I.B. Tauris, 2005.

BOLTER Jay David and Richard GRUSIN, Remediation: Understanding New Media, Cambridge (MA), MIT Press, 1999.

BEIRNE Rebecca Clare, "Embattled Sex: Rise of the Right and Victory of the Queer in Queer As Folk", in The New Queer Aesthetic on Television: Essays on Recent Programming, ed. James R. Keller and Leslie Stratyner, Jefferson, North Carolina, McFarland, 2006, p. 43-58.

Chambers Samuel A., The Queer Politics of Television, London, I.B. Tauris, 2009.

Clarke M. J., Transmedia Television: New Trends in Network Serial Production, London, Bloomsbury, 2013.

DAvis Glyn, Queer As Folk, Norfolk, Cromwell Press, 2007 [London: British Film Institute, 2007].

Davis Glyn and Gary NeEDHAM (ed.), Queer TV: Theories, Histories, Politics, New York, New York, Routledge, 2009.

EDWARDS Natalie, “From Minority to Mainstream: Channel 4's Queer Television”, The Journal of e-media Studies, Vol. 2, No. 1, 2009, Dartmouth College:

http://journals.dartmouth.edu/cgibin/WebObjects/Journals.woa/1/x mlpage/4/article/325

FrIEDBERG Anne, “The Virtual Window”, in Rethinking Media Change: The Aesthetics of Transition, ed. David Thornburn and Henry Jenkins, Cambridge, Massachusetts, MIT Press, 2004 [2003], p. 337-354.

GRUSIN Richard, Premediation: Affect and Mediality After 9/11, New York, Palgrave Macmillan, 2010.

HunTING Kyra, "Queer As Folk and the Trouble with Slash", TWC (Transformative Works and Cultures), Vol. 11, 2012.

http://journal.transformativeworks.org/index.php/twc/article/view/4 $15 / 315$

Hutcheon Linda, A Theory of Adaptation, New York, Routledge, 2006. 
JEFFords Susan, Hardbodies: Hollywood Masculinity in the Reagan Era, New Brunswick, New Jersey, Rutgers University Press, 1994.

Keller James R. and Leslie Stratyner (ed.), The New Queer Aesthetic on Television: Essays on Recent Programming, Jefferson, North Carolina, McFarland, 2006.

LUDOT-VLASAK Ronan, "Canon Trouble: Intertextuality and Subversion in Queer As Folk", TV/Series, No. 2, November 2012, Le Havre University (TV Series in the World: Exchanging Places, Places of Exchange, ed. Sylvaine Bataille and Sarah Hatchuel): http://www.univ-lehavre.fr/ulh services/IMG/pdf/15 LUDOTVLASAK_Ronan.pdf

McCloud Scott, Understanding Comics, New York, New York, Harper Perennial, 1994 [1993].

Webcomics:

http://www.scottmccloud.com/1-webcomics/index.html

Murray Simone, "Brand Loyalties: Rethinking Content Within Global Corporate Media”, Media, Culture and Society, Vol. 27, May 2005, p. 413-435.

PeEREN Esther, "Queering the Straight World: The Politics of Resignification in Queer As Folk", in The New Queer Aesthetic on Television: Essays on Recent Programming, ed. James R. Keller and Leslie Stratyner, Jefferson, North Carolina, McFarland, 2006, p. 59-74.

Russo Julie Levin, "Inside the Box: Accessing Self-Reflexive Television", The Journal of e-media Studies, Vol. 2, No. 1, 2009, Dartmouth College.

http://journals.dartmouth.edu/cgi-

bin/WebObjects/Journals.woa/1/xmlpage/4/article/324

Thorburn David and Henry JEnkins (ed.), Rethinking Media Change: The Aesthetics of Transition, Cambridge, Massachusetts, MIT Press, 2004 [2003].

\section{The author}

Monica Michlin is an Associate Professor of American Literature at ParisSorbonne (Paris-4). She has published articles on African-American literature, 
on contemporary American film, and on recent TV series. The latter publications include: "Starting Off with a Bang: the Whirl of Reflexive and Metatextual Images in the Pilot Episodes to Three $A B C$ Series: Desperate Housewives, Lost and Flashforward." (2012); "The American Presidency and the $25^{\text {th }}$ Amendment in Contemporary TV Series: Fiction, Reality, and the Warped Mirrors of the Post-9/11 Zeitgeist" (2012) and "More, More, More: Contemporary American TV Series and the Attractions and Challenges of Serialization As Ongoing Narrative.” (2011). She is currently co-writing a book on dreams and scripts in contemporary American TV series with Sarah Hatchuel, to be published in 2015 . 